\title{
11. A GYAKORLÓISKOLA SZEREPE A TANÁRJELÖLTEK FELKÉSZÍTÉSÉBEN
}

\author{
ORGOVÁNYI-GAJDOS JUDIT
}

\section{Bevezetés}

A magyarországi tanárképzés az ún. párhuzamos („concurrent”) képzési modell segítségével írható le, ami azt jelenti, hogy a hallgatók elméleti és szakmai gyakorlati képzése a tanulmányi időben egymással párhuzamosan történik (European Commission, 2015). A magyar tanárképzés rendszerében több szerkezeti változtatás is történt. 2006-2012 között a bolognai rendszerben tanultak a hallgatók, majd a 2013/2014-es tanévben bevezették az osztatlan (5 plusz 1 éves) képzést. A hazai kutatási eredmények azonban azt mutatták, hogy a változások ellenére a tanárképzés alapvető elemei megmaradtak, és maga a képzés nem vált hatékonyabbá (Stéger, 2014). A felmérések rámutattak arra, hogy a pedagógusképzésben részt vevő hallgatók képzéssel kapcsolatos elvárásai nem minden esetben teljesülnek. A jelöltek úgy érzik, az egyetemi képzés nem szentel kellő figyelmet azon kompetenciák fejlesztésére, amelyekre igazán szükségük lenne a tanulási-tanítási folyamat hatékony irányításához (Kocsis, 2003; Lukács, 2002; Jancsák, 2011, 2012). Az egyik ilyen terület az osztályirányítás (fegyelmezés, csoportirányítás, konfliktuskezelés), a másik az egyéni bánásmódot igénylő tanulók köre (SNI, tehetséges tanuló), a harmadik a szülőkkel való együttműködés (N. Kollár, 2011; Jancsák, 2012). Ezek az adatok egybecsengenek a kezdő pedagógusok kihívásaival foglalkozó hazai és nemzetközi kutatásokkal is (Hagger és McIntyre, 2006; OECD, 2009; Fehérvári, 2016; Sági és Szemerszki, 2016).

A magyar tanárképzés a hagyományos, egyetemközpontú („university-based) modell szerint valósul meg, melyben a gyakorlóiskola jogilag és szervezetileg is az egyetemi képzőhelyhez tartozik. Ebben a felállásban az egyetem határozza meg a képzési szerkezetet, a gyakorlóiskola szerepét, feladatait a fennálló törvényi szabályozás keretén belül. A szakirodalom az ilyen típusú képzést más néven az elmélettől a gyakorlat irányába haladó („Theory to practice model”) vagy az elméletet alkalmazó („Application of theory model”) modellnek nevezi (Carlson, 1999; Korthagen és Kessels, 1999). A tanárképzéshez kapcsolódó feladatokat tekintve egyfajta kiegészíto, partneri kapcsolatot feltételez (vö.: „,complementary university-school partnership”), amely szerint bizonyos feladatköröket megoszt az egyetem és a gyakorlóiskola. A probléma ugyanakkor az, hogy a valódi integráció nem valósul meg (Furlong, 2006). Ennek fóbb okai 
lehetnek a nemzetközi kutatások által is beazonosított hiányok, mint az egyetem elméleti képzésében a szaktudományi, pszichológiai és pedagógiai kurzusok széttöredezett, mozaikos szerkezete, az elméleten alapuló gyakorlati oktatás hiánya, túl nagy hangsúly az egyéni tudás, kompetenciák fejlesztésén, a pedagógusok együttmüködésének fejlesztésére vonatkozó fókusz hiánya (Feiman-Nemser, 2001; Darling-Hammond, 2006). Az egyetemi kurzusok egymástól és a valós pedagógiai gyakorlattól való elszigeteltsége, az együttműködő képesség fejlesztésének hiánya számos kihívással szembesítik a kezdő tanárokat. Ilyen a pedagógiai és pszichológiai ismeretek összehangolása és alkalmazása, illetve olyan gyakorlati készségek hiánya, amelyek révén megvalósulna a hatékony óravezetés, a szülőkkel való együttműködés vagy éppen a tanulók egyéni tanulási igényeihez való igazodás (Putnam és Borko, 2000; Hagger és McIntyre, 2006; Vick, 2006; Jensen és mtsai., 2012).

A szakmai fejlesztö iskola (Professional Development School, PDS) modellje azért lehet iránymutató e tekintetben, mert felhívja a figyelmet arra, hogy a tanárképzésben részt vevő intézményeknek a gyermekek és a hallgatók tanulási szükségleteire épülő kutató-fejlesztő munkát középpontba állitó, közös problémamegoldásra épülő együttműködése elengedhetetlen ahhoz, hogy a képzés céljai ténylegesen megvalósuljanak, és a pedagógusjelölt hallgatók felkészitése hatékonnyá váljon. Ennek alapfeltétele, hogy a képzéshez kapcsolódó partnerintézmények, illetve a tanárképzésben érintett résztvevők között egyenrangú viszony alakuljon ki. A koncepció kihangsúlyozza azt is, hogy a szakmai tanulóközösség tagjai az egyetem és a gyakorlóhely oktatóin kívül más külső oktatók (pl. gyógypedagógus), valamint a szülők is, akik hasznos információkkal szolgálhatnak a tanárjelöltek számára (Darling-Hammond, 1994).

A részkutatás célja, hogy a szakmai fejlesztő iskola (SZFI) koncepciójának tükrében feltárja a gyakorlóiskola tanárképző funkciójához kapcsolódó erősségeit és fejlesztendő területeit a tanárképzés részt vevő hallgatók, az egyetemen tanító szakmódszertanos oktatók és az egri gyakorlóiskolában tanító pedagógusok nézetei, attitüdjei és véleményei alapján.

A vizsgálat a SZFI mint tanulószervezet öt fö jellemzője mentén történt (The Holmes Group, 1986, 1990; Garvin, 1993):

- problémaérzékenység, szisztematikus (rendszerszintü) problémamegoldás: a szervezet tagjai precízen és pontosan törekednek a problémák megoldására kiindulva a nyilvánvaló hiányosságokból, értékelve azok kiváltó okait;

- kísérletezés: a szervezet tagjai rendszeresen végeznek kutatásokat, és tesztelik az újonnan kialakított tudást a horizontok kitágítása érdekében;

- egymástól való tanulás lehetőségei: szervezeten belüli és szervezetek közötti formális és informális tanulási folyamatokat takar;

- tapasztalatokra épülő tanulás: a szervezet számára elengedhetetlen, hogy folyamatosan és szisztematikusan felülvizsgálják, értékeljék tapasztalataikat (sikereiket, kudarcaikat), és erre építsék fejlesztési tevékenységeiket; 
- tudásmegosztás: a szervezet tagjai részt vesznek a felhalmozott tudás, tapasztalat gyors és hatékony megosztásában. A tudás a szervezeten belül mindenki számára elérhető.

\section{A részkutatás mintája és módszere}

A tanárképzés folyamatában a gyakorlóiskolák a tanítási gyakorlatok során jutnak szerephez Az Eszterházy Károly gyakorlóiskolában zajló gyakorlati felkészítés célját, módját és speciális területeit az Útmutató című dokumentumok (Sándor, 2011; Dudás, 2011) deklarálják, melyek a tanári mesterképzési szakhoz kapcsolódó 15/2006. (IV.3.) OM rendelet előírásai alapján készültek. Az iskolai gyakorlatok három típusa jelenik meg a mesterképzésekben (1. táblázat). Az első a Nevelési-oktatási gyakorlat, melynek célja, hogy a hallgatók kapcsolatba kerüljenek az iskola belső világával, az iskolai dokumentumokon és saját tapasztalataikon keresztül megismerjék az iskola szerkezetét, döntési mechanizmusait. A hallgatók a gyakorlat során dokumentumelemzést, kérdőíves vizsgálatot, mikrotanítást végeznek, interjúkat készítenek és hospitálnak, amihez a pedagógiai és pszichológiai tárgyak oktatóitól és a gyakorlóiskola szakvezetőitől kapnak segítséget. A gyakorlat időtartama 45 óra +1 hetes gyakorlóiskolai gyakorlat (Dudás, 2011). Az Iskolai tanitási gyakorlat két ütemben, két szemeszterben történik. A szakmai gyakorlat célja a szaktárgy ismeretanyagának oktatásához (tervezéshez, órairányításhoz és értékeléshez) szükséges tanári kompetenciák fejlesztése. A hospitálások mellett a hallgató összesen 15 órát tanít, és a gyakorlat zárótanítással zárul (Sándor, 2011). Az Összefüggő, egyéni szakmai gyakorlat egy több hónapos folyamatot ölel fel, amely a gyakorlóiskolától független közegben zajlik. Az iskolai gyakorlatok tapasztalatait rögzítő dokumentumokat a hallgatóknak portfólióba kell rendezniük (Magyar, 2011).

\section{A három gyakorlat közül az Eszterházy Károly Egyetem hallgatói az elsö kettöt végzik a gyakorlóiskolában.}




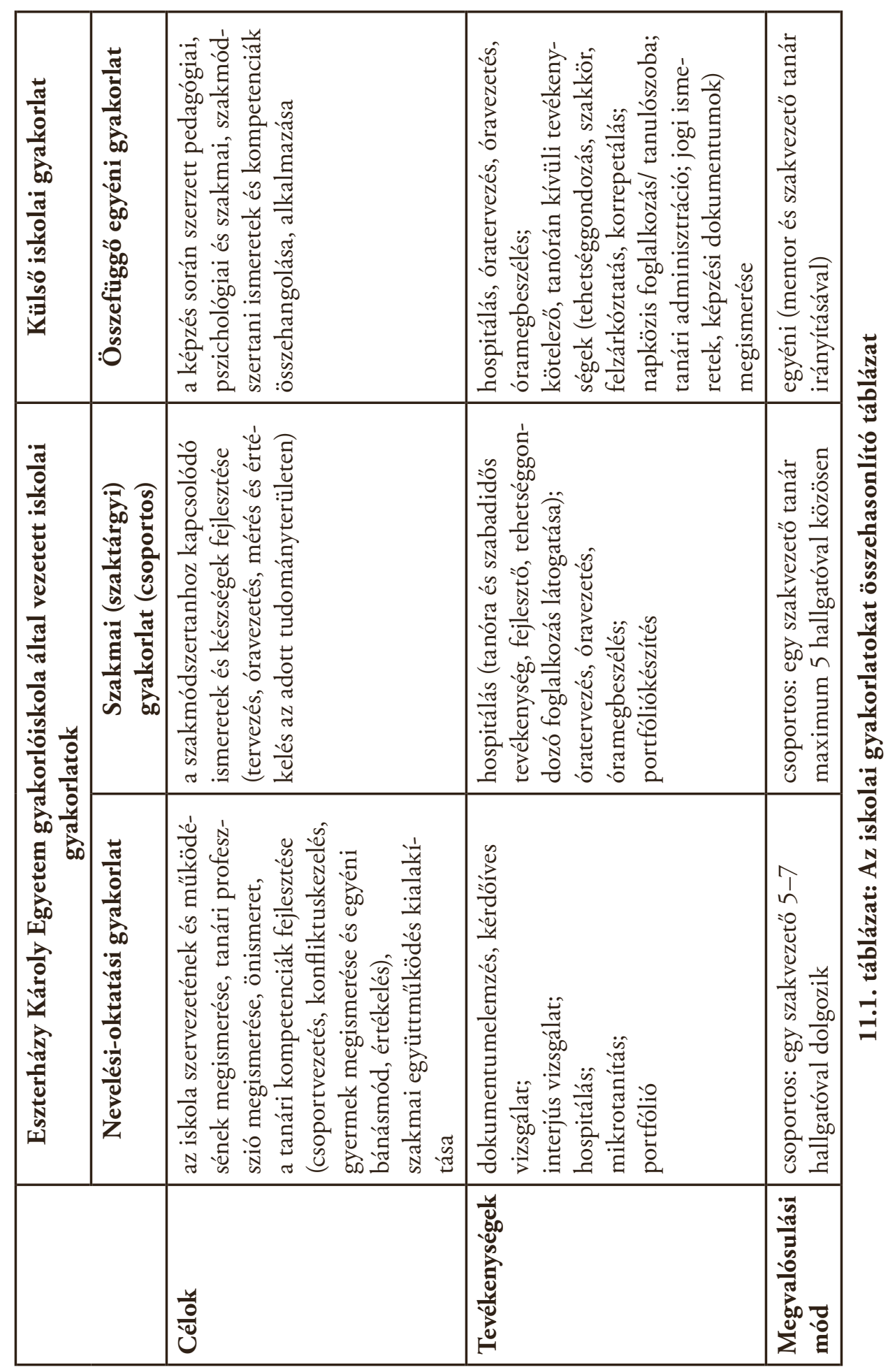


A 2017-ben történt vizsgálat mintája három csoportot foglalt magába. Az egyik csoport tagjai az Eszterházy Károly Egyetem gyakorlóiskolájában dolgozó pedagógusok $(\mathrm{N}=102)$, köztük a szakvezetőkkel ( $\mathrm{N}=34)$. A második csoport az Eszterházy Károly Egyetem gyakorlóiskolájában tanuló felső tagozatos diákok $(\mathrm{N}=255)$. A harmadik mintacsoport az egyetem szakmódszertanos oktatói $(\mathrm{N}=20)$, a negyedik csoportot pedig azok a hallgatók alkották, akik a kutatás alatt végezték csoportos szakmai gyakorlatukat a gyakorlóiskolában $(\mathrm{N}=22)$.

A résztéma vizsgálati módszere a kérdőív volt. A saját fejlesztésű online kérdőívek a résztémához kapcsolódó skálás, feleletválasztós és nyílt kérdéseket tartalmaztak. A skálák ötfokozatú attitűdskálák voltak. Az adatokat leíró és matematikai statisztikai vizsgálatoknak vetettük alá, a nyílt kérdésekre adott válaszokkal tartalomelemzést végeztünk nyílt kódolással. A tartalomelemzésnél a megbízhatóságot interkódolással biztosítottuk. Megbízhatósági mutatónk 0,6 és 1 közé esik (Dafinoiu és Lungu, 2003; Lombard, és mtsai., 2005), ezért a kódolást megbízhatónak nyilvánítottuk.

\section{A vizsgálat kutatási kérdései}

A részkutatás a szakmai fejlesztő iskola (SZFI) koncepciójának tükrében a következő kérdésekre kereste a választ:

\section{A tanárjelöltek felkészitésének tartalmi összehangolása (rendszerszintü gondolkodás):}

- Milyen mértékben azonos a hallgatók és a vezetőtanárok megítélése az egyetemi kurzusok, illetve az iskolai gyakorlatok tanári professzióra való felkészülésben betöltött szerepét illetően?

- Mekkora a koherencia a hallgatók szaktárgyi (tudományos), pedagógiai-pszichológiai és szakmódszertani (tantárgypedagógiai) felkészültségét illetően a hallgatók, az oktatók és a vezetőtanárok véleménye között? Mennyire elégedettek a hallgatók, egyetemi oktatók és pedagógusok az egyetemi képzés és az iskolai gyakorlatok közötti tartalmi összhanggal?

A tanárjelöltek kisérletezési lehetöségei a gyakorlótanitások során:

- Milyen mértékben jellemző, hogy a hallgatóknak lehetőségük van saját ötleteik megvalósítására?

- Milyen típusú foglalkozásokon volt lehetőségük a jelölteknek foglalkozásvezetőként is kipróbálni magukat?

Az egymástól való tanulás lehetöségei:

- Milyen mértékben támogatja a képzés, hogy a tanárjelöltek betekintést nyerjenek az intézményben folyó szakmai együttműködésbe? 
- Milyen mértékben támogatták a csoportos gyakorlatok a tanárjelöltek tanulókkal, pedagógusokkal és szülőkkel való együttműködésének megtapasztalását?

A tanárjelöltek saját tapasztalataira épülö tanulás támogatása:

- Milyen feladatok és tevékenységek segítik a hallgatók szakmai fejlődését az iskolai gyakorlatok során?

- Hogyan jellemezhető a tanárjelöltek szakmai fejlődése az iskolai gyakorlatokat illetően?

- Milyen változtatásokra lenne szükség az iskolai gyakorlatokat illetően a hallgatók és az oktatók szerint?

A tudásmegosztás lehetöségei:

- Az iskolai csoportos gyakorlatokhoz kapcsolódó tudásmegosztás milyen irányultságú és kiterjedtségü?

\section{A kérdőíves vizsgálat eredményei}

Az eredmények bemutatásához a gyakorlóiskolai tanulók $(\mathrm{N}=255)$, a pedagógusok $(\mathrm{N}=102)$ és az egyetemi szakmódszertanos oktatók $(\mathrm{N}=20)$ vonatkozó válaszait elemeztük. A kutatási kérdéseket Likert-skálás, többválasztós és nyílt kérdésekkel vizsgáltuk.

\subsection{A tanárjelöltek felkészítésének tartalmi összehangolása (rendszerszintü gondolkodás)}

Ebben a témakörben azt vizsgáltuk, hogy a tanárjelöltek felkészítésében milyen mértékben figyelhető meg a tartalmi összehangoltság a hallgatók, a gyakorlóiskolai pedagógusok és az egyetemi szakmódszertani oktatók szerint.

A három mintába tartozókat (pedagógus, hallgató, oktató) megkértük, hogy ötfokú skálán jelöljék, hogy általánosságban hogyan ítélik meg az elméleti és a gyakorlati képzés tartalmi összhangját a tanárképzésben. Összességében a legelégedettebbeknek a vezetőtanárok (M: 3.49, SD: .96) bizonyultak, de csupán 7\%-uk teljesen elégedett a két intézmény közötti összhanggal, a minta 60\%-a az „inkább elégedett” kategóriát jelölte meg (2. táblázat). A legelégedetlenebbnek a jelöltek bizonyultak (M: 3.0, SD: .55), csak 5,5\%-uk teljesen elégedett a kérdéses témával, 28\%-uk inkább elégedett, 28\%-uk elégedett is, meg nem is, és 39\%-uk inkább nem elégedett. Az egyetemi oktatók válaszainak átlagértéke az ötfokú skálán 3,3 (M: 3.3, SD: .78) lett. 


\begin{tabular}{|c|c|c|c|c|c|}
\hline & 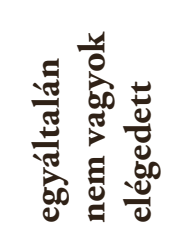 & 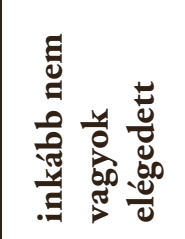 & 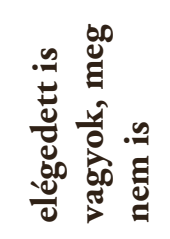 & 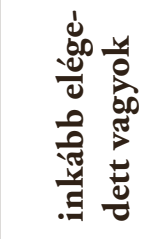 & 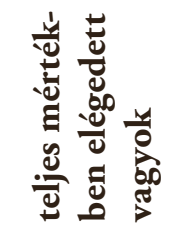 \\
\hline $\begin{array}{l}\text { Egyetemi oktatók } \\
(\mathrm{N}=20)\end{array}$ & $0 \%$ & $19 \%$ & $38 \%$ & $38 \%$ & $6 \%$ \\
\hline $\begin{array}{l}\text { Tanárjelöltek } \\
(\mathrm{N}=22)\end{array}$ & $0 \%$ & $39 \%$ & $28 \%$ & $28 \%$ & $6 \%$ \\
\hline $\begin{array}{l}\text { Gyakorlóiskolai veze- } \\
\text { tőtanárok }(\mathrm{N}=43)\end{array}$ & $5 \%$ & $12 \%$ & $21 \%$ & $56 \%$ & $7 \%$ \\
\hline
\end{tabular}

11.2. táblázat: Az egyetemi képzés és az iskolai gyakorlatok tartalma közötti összhang az egyetemi oktatók, a tanárjelöltek és a gyakorlóiskolai tanárok (vezetőpedagógusok) szerint

Egy többválasztós kérdéssel vizsgáltuk a pedagógusjelöltek és a gyakorlóiskolai tanárok véleményét a képzőintézmények képzésben betöltött szerepét illetően. 19 elemből maximum 5 kategóriát megjelölve kellett a mintákban szereplő alanyoknak kiválasztaniuk, hogy az egyetem, illetve a gyakorlóiskola mely területeken támogatja leginkább a tanári professzióra való felkészülést. Az elemzés során kiderült, hogy a gyakorlóiskolában tanító tanárok és a hallgatók eltérőképpen vélekednek az egyetem és gyakorlóiskola által nyújtott felkészítésről az egyes területeket illetően. 


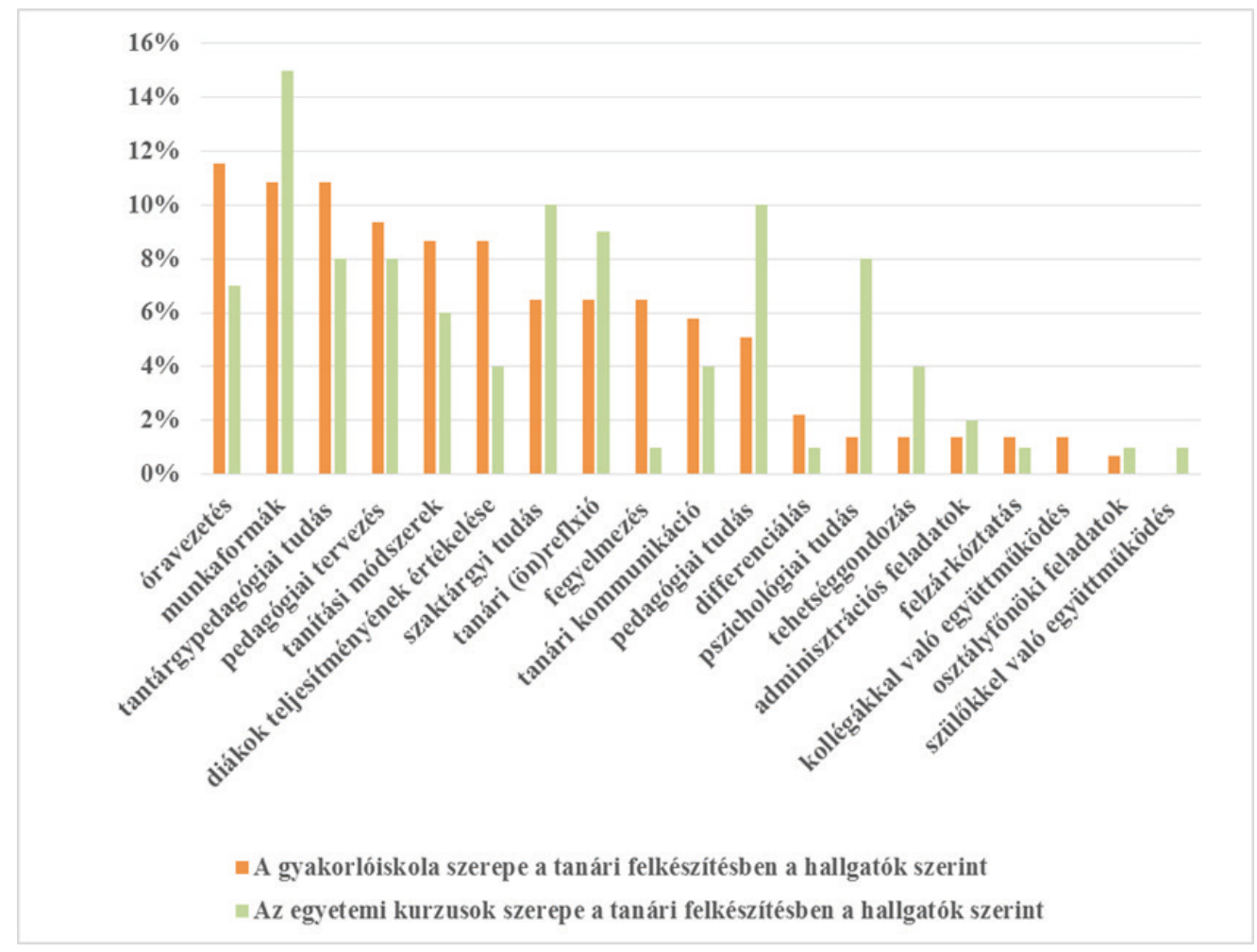

\section{1. ábra: A gyakorlóiskola és az egyetemi kurzusok szerepe a tanári felkészítésben a hallgatók véleménye alapján (relatív gyakoriság, $\mathrm{N}=22$ )}

Az adatok azt mutatták, hogy a hallgatók szerint a gyakorlóiskola messze nagyobb szerepet tölt be az óratervezési, -vezetési és tantárgy-pedagógiai tudásuk fejlesztésében, valamint munkaformák és módszerek alkalmazásához kapcsolódó készségeik fejlesztésében. Az egyetemi kurzusok meglátásuk szerint elsősorban pedagógiai, szaktárgyi, pszichológiai tudásuk és (ön)reflexiós képességeik fejlesztését szolgálják (1. ábra). 


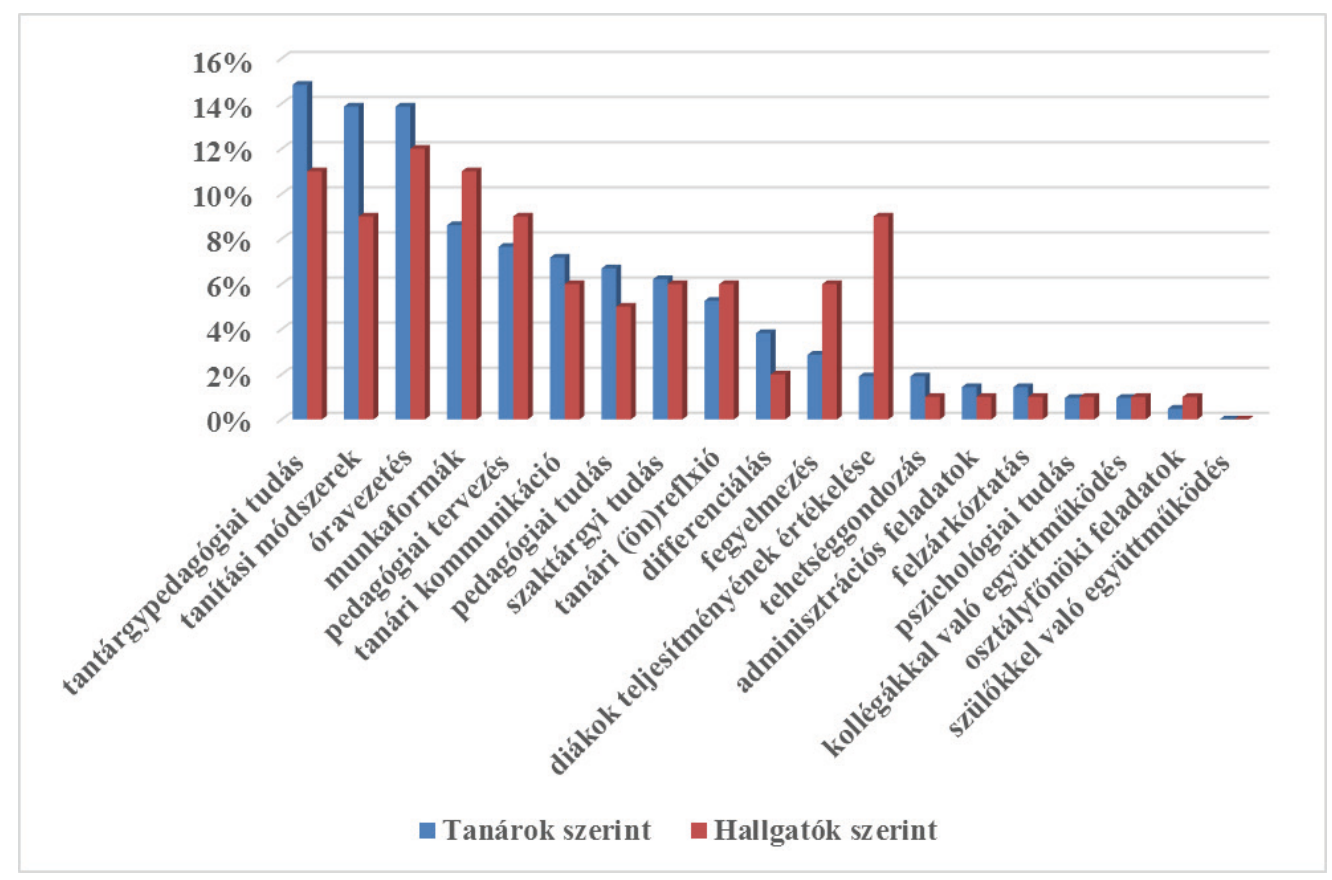

\section{2. ábra: A gyakorlóiskola szerepe a tanári professzióra való felkészítés egyes területeit illetően a pedagógusok és a hallgatók szerint (relatív gyakoriság: hallgató: $\mathrm{N}=22$; pedagógus: $\mathrm{N}=102$ )}

Bár szignifikáns különbségek voltak kimutathatók a gyakorlóiskola pedagógusai és a tanárjelöltek véleményében a gyakorlóiskola szerepét illetően, mindkét csoport egyetértett abban, hogy a rövid gyakorlatok nagyfokú fejlesztő hatással bírnak a jelöltek tantárgy-pedagógiai és óravezetéssel kapcsolatos tudására. Voltak azonban olyan területek, ahol a tanárjelöltek a gyakorlóiskola intenzívebb szerepét emelték ki, mint például a tanulók értékelése, a fegyelmezés, az óravezetés, a különböző munkaformák alkalmazása (2. ábra).

A pedagógusok és a tanárjelöltek egyetértettek abban, hogy az egyetemi kurzusok jelentős mértékben hozzájárultak a tantervi tudásuk és az általános pedagógiai-pszichológiai tudásuk fejlesztéséhez, a pedagógusok mégis markánsabban képviselték ezt a véleményt. A különböző munkaformák, a reflektivitás fejlesztése, az óravezetés, a tehetséggondozás esetében a pedagógusok kevésbé tartották fontosnak az egyetem szerepét. (3. ábra) 


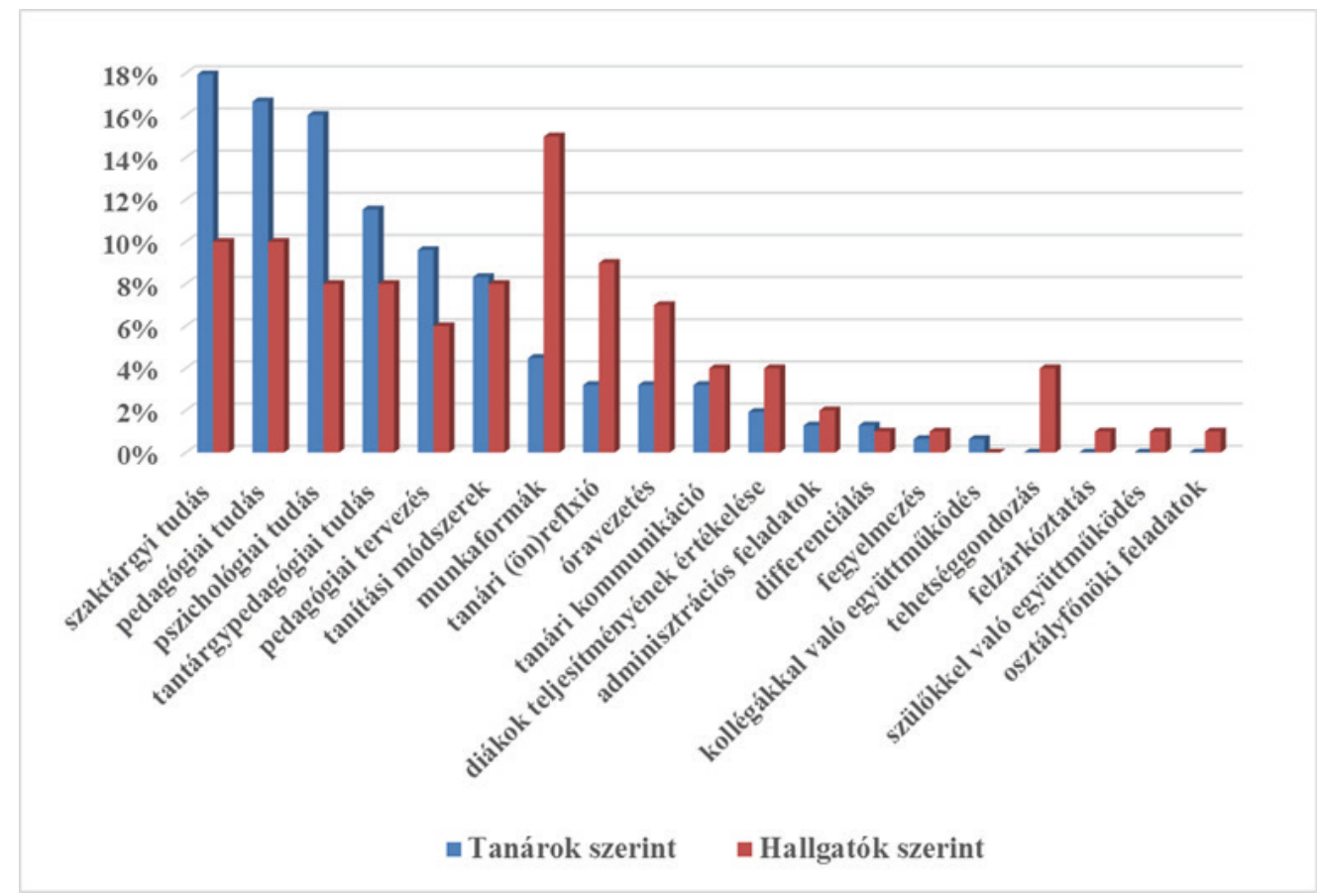

11.3. ábra: Az egyetemi kurzusok szerepe a tanári professzióra való felkészítés egyes területeit illetően a vezetőtanárok és a hallgatók szerint (relatív gyakoriság: vezetőtanárok: $\mathrm{N}=34$, hallgatók: $\mathrm{N}=22$ )

Az adatok arra is rámutatnak, hogy a kollégákkal és szülőkkel való együttműködés képessége sem az egyetemi képzés, sem pedig az iskolai gyakorlat esetében nem igazán fejlődött a két csoport véleménye szerint. Ugyanez elmondható az osztályfönöki szerepkörhöz kapcsolódó kompetenciák fejlesztése terén is.

A mintában szereplők véleményét összehasonlítva elmondható, hogy a gyakorlóiskola és az egyetem tartalma nincs teljesen szinkronban. A hallgatók és a vezetőtanárok eltérőképpen érzékelik a két intézmény szerepét a tanári professzióra való felkészítésben.

\subsection{A tanárjelöltek kísérletezési lehetőségei a gyakorlótanítások során}

A tanárjelölteket kísérletezési lehetőségeit vizsgálva a következőket állapíthatjuk meg. A bonyolultabb szervezést igénylő tanórai tevékenységekre vonatkozóan elmondható, hogy a jelöltek 36\%-ának volt lehetősége csoportmunkára építő tanórai foglalkozást, 14\%-ának differenciált tanórai foglalkozást megvalósítani. (3. táblázat) A tanórán kívüli tevékenységek közül leginkább a sportesemények, edzések vezetésében volt alkalmuk aktívan részt venni (32\%). A jelöltek 23\%-ának volt lehetősége osztályfönöki órát tartani. A jelöltek csupán 
14\% -a jelezte, hogy lehetősége volt iskolai rendezvények, felzárkóztató és szabadidős foglalkozások vezetésébe bekapcsolódni. Fogadóórát, szülői értekezletet, tehetséggondozó, illetve tanulásmódszertani foglalkozásokat a jelöltek nem tartottak.

Összességében elmondható, hogy a jelöltek 63\%-a úgy érezte, hogy alapvetően megvalósíthatta saját nevelési-oktatási ötleteit, csupán 13\%-uk érezte teljesen az ellenkezőjét. Azzal, hogy önállóan oldhattak meg pedagógiai feladatokat, a jelöltek 68\%-a egyetértett. A jelöltek visszajelzései alapján tehát volt néhány lehetőségük saját ötleteik megvalósítására (M: 3.8, SD: 1.2), és bizonyos feladatokat önállóan tudtak végrehajtani (M: 3.9, SD: .19).

\begin{tabular}{|l|l|l|}
\hline & $\begin{array}{l}\text { „Hospitáltam ilyen } \\
\text { alkalmon” }\end{array}$ & $\begin{array}{l}\text {,Részt vettem } \\
\text { a megvalósításában” }\end{array}$ \\
\hline $\begin{array}{l}\text { Differenciált tanórai foglalkozás } \\
\text { Csoportmunkára építő tanórai }\end{array}$ & $14 \%$ & $14 \%$ \\
foglalkozás & $50 \%$ & $36 \%$ \\
\hline Fogadóóra & $0 \%$ & $0 \%$ \\
Felzárkóztató foglalkozás & $\% \%$ & $14 \%$ \\
Osztályfónöki óra & $5 \%$ & $23 \%$ \\
Fejlesztő foglalkozás & $27 \%$ & $5 \%$ \\
Szülői értekezlet & $9 \%$ & $0 \%$ \\
Tehetséggondozó foglalkozás & $18 \%$ & $9 \%$ \\
Szakköri/sportköri foglalkozás & $41 \%$ & $31 \%$ \\
Tanulószobai/napközis foglalkozás & $18 \%$ & $9 \%$ \\
Iskolai rendezvények & $32 \%$ & $14 \%$ \\
Szabadidős foglalkozás & $27 \%$ & $14 \%$ \\
Tanulásmódszertani foglalkozás & $14 \%$ & $0 \%$ \\
\hline
\end{tabular}

11.3. táblázat: Tanórai és tanórán kívüli foglalkozások, melyeken hospitált és amelyek megvalósításában részt vett a hallgató (relatív gyakoriság, $\mathrm{N}=22$, hallgatói kérdőív 10., 11. kérdés)

\subsection{Az egymástól való tanulás lehetőségei a tanárjelöltek szemszögéből}

A gyakorlóiskola egyik legfontosabb célja, hogy „támogassa, hogy a tanárjelöltek minél szélesebb betekintést nyerjenek a pedagógusok, iskolai támogató munkatársak, szülők együttműködésébe”. A kérdéskört ötfokú Likert-skálával vizsgáltuk. Az adatok alapján kirajzolódott, hogy a hallgatók 70\%-a úgy érezte, nem láthatott bele a nevelőtestület működésébe, és csak 14\%-a érezte úgy, hogy teljesült ez iránti igénye. Csupán 4\%-a érzékelte úgy, hogy része lehetett a nevelőtestületnek mint szakmai közösségnek. A hallgatók szintén kisebb 
százaléka jelezte azt, hogy a szervezeti kultúrát meghatározó iskolai rendezvényekben részt tudott venni. A gyermekvédelmi felelős, illetve a gyógypedagógus szakmai feladataiba és kapcsolatrendszerébe a jelöltek nem tudtak bepillantást nyerni. A szülókkel való kapcsolat kialakítására sem nyílt lehetőségük. (4. táblázat)

\begin{tabular}{|c|c|c|c|c|c|}
\hline & 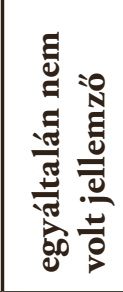 & 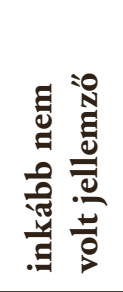 & 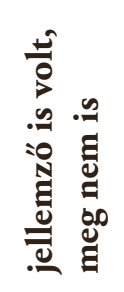 & 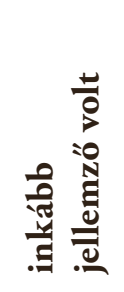 & 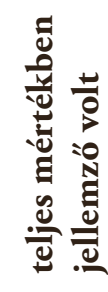 \\
\hline $\begin{array}{l}\text { Képet kaphattam a nevelötestület } \\
\text { müködéséröl. }\end{array}$ & $41 \%$ & $18 \%$ & $18 \%$ & $9 \%$ & $13 \%$ \\
\hline $\begin{array}{l}\text { Lehetőségem nyílt nevelőtestületi } \\
\text { értekezleteken részt venni. }\end{array}$ & $77 \%$ & $5 \%$ & $0 \%$ & $9 \%$ & $9 \%$ \\
\hline $\begin{array}{l}\text { Része lehettem a nevelőtestületnek } \\
\text { mint szakmai közösségnek. }\end{array}$ & $64 \%$ & $9 \%$ & $22 \%$ & $0 \%$ & $5 \%$ \\
\hline $\begin{array}{l}\text { Részt vehettem az iskola hagyományá- } \\
\text { poló tevékenységében. }\end{array}$ & $41 \%$ & $9 \%$ & $14 \%$ & $18 \%$ & $18 \%$ \\
\hline $\begin{array}{l}\text { Kapcsolatot alakíthattam ki } \\
\text { a szüilőkkel. }\end{array}$ & $86 \%$ & $14 \%$ & $0 \%$ & $0 \%$ & $0 \%$ \\
\hline $\begin{array}{l}\text { Lehetőségem volt a gyermekvédelemi } \\
\text { felelős munkájába bepillantást nyerni. }\end{array}$ & $45 \%$ & $27 \%$ & $18 \%$ & $0 \%$ & $9 \%$ \\
\hline $\begin{array}{l}\text { Lehetőségem volt a gyógypedagógus } \\
\text { munkájába bepillantani. }\end{array}$ & $50 \%$ & $18 \%$ & $18 \%$ & $0 \%$ & $14 \%$ \\
\hline
\end{tabular}

11.4. táblázat: A tanárjelöltek betekintési lehetősége az iskolai szintû́ szakmai együttmúködésbe ( $\mathrm{N}=22$, relatív gyakoriság)

A tanárok $80 \%$-a fontosnak tartja a hallgatók visszajelzéseit, és úgy véli, a jelöltekkel való együttműködés megfelelő szintủ. Hasonló arányban (72\%-uk) ugyanezt nyilatkozták az egyetemi oktatókkal kapcsolatban is, 66\%-uk pedig úgy gondolja, hogy az egyetemi oktatókkal való együttműködés is kiváló. (5. táblázat) 


\begin{tabular}{|c|c|c|c|c|c|}
\hline & 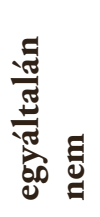 & 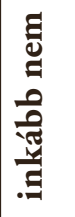 & 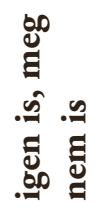 & 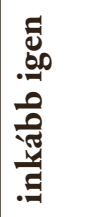 & ֻ \\
\hline $\begin{array}{l}\text { Elégedettség az egyetemi } \\
\text { oktatókkal való } \\
\text { együttmüködéssel }\end{array}$ & $12 \%$ & $8 \%$ & $29 \%$ & $42 \%$ & $20 \%$ \\
\hline $\begin{array}{l}\text { Elégedettség } \\
\text { a tanárjelöltekkel való } \\
\text { együittmüködéssel }\end{array}$ & $0 \%$ & $4 \%$ & $19 \%$ & $56 \%$ & $22 \%$ \\
\hline $\begin{array}{l}\text { A tanárjelöltek } \\
\text { visszajelzéseinek fontossága }\end{array}$ & $4 \%$ & $7 \%$ & $9 \%$ & $37 \%$ & $43 \%$ \\
\hline $\begin{array}{l}\text { Az egyetemi oktatók } \\
\text { visszajelzéseinek fontossága }\end{array}$ & $4 \%$ & $9 \%$ & $14 \%$ & $35 \%$ & $38 \%$ \\
\hline
\end{tabular}

11.5. táblázat: A gyakorlóiskolai tanárok visszajelzésekkel kapcsolatos attitüdjei és elégedettsége a tanárjelöltekkel és az egyetemi oktatókkal való együttmüködésre vonatkozóan (relatív gyakoriság, $\mathrm{N}=102$ )

A tanulók válaszaiból kiderül, hogy a tanárjelöltek nem folynak bele az osztályok életébe. A tanulók csupán 26\%-a érzékeli úgy, hogy a jelöltek részt vesznek a tanítók által szervezett programokon, illetve maguk is szerveznek programokat a csoportoknak. Illetve a tanulók csupán 28\%-a érzékeli úgy, hogy a jelöltek beszélgetnek velük órákon kívül. (6. táblázat)

\begin{tabular}{|c|c|c|c|c|c|}
\hline & 总 & 总 & 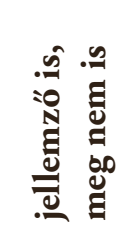 & 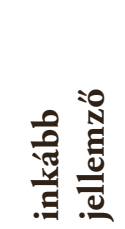 & 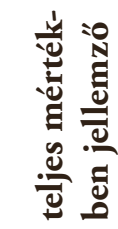 \\
\hline $\begin{array}{l}\text { Órákon kívül is beszélgetnek } \\
\text { velünk. }\end{array}$ & $25 \%$ & $21 \%$ & $26 \%$ & $18 \%$ & $10 \%$ \\
\hline $\begin{array}{l}\text { Részt vesznek velünk a tanítónk } \\
\text { által szervezett programokon is. }\end{array}$ & $13 \%$ & $23 \%$ & $38 \%$ & $20 \%$ & $6 \%$ \\
\hline $\begin{array}{l}\text { Ök is szerveznek programokat } \\
\text { neküink. }\end{array}$ & $24 \%$ & $25 \%$ & $26 \%$ & $19 \%$ & $7 \%$ \\
\hline
\end{tabular}

11.6. táblázat: Tanulók tanárjelöltekkel kapcsolatos vélekedése (relatív gyakoriság, $\mathrm{N}=255$ ) 


\subsection{A tanárjelöltek saját tapasztalataira épülö tanulás támogatása}

\section{A csoportos gyakorlatokhoz kapcsolódó kutatási tevékenységek}

A visszajelzésekből az derül ki, hogy a tanárjelöltek közel felének volt lehetősége a gyakorlóiskolai kutatási tevékenységekkel kapcsolatos elvárásokat teljesíteni. Habár a gyakorlótanításhoz kapcsolódó Útmutató kötelezően két interjú és egy kérdőíves vizsgálat elvégzését írja elő, a hallgatók átlagosan közepes mértékben jelezték vissza ennek lehetőségét, ami azt jelenti, hogy a megkérdezettek fele tudta csak teljesíteni az elvárásokat (7. táblázat). A kérdés az, hogy ennek a feltételek hiánya vagy hallgatói mulasztás volt az oka.

Az iskolai dokumentumok megismerése a gyakorlótanításhoz kapcsolódó Útmutató követelménye szerint önállóan kell hogy megtörténjen a honlapon található információk alapján. A hallgatók azonban átlagosan közepes mértékben (M: 3.64, SD: 1.39) értettek egyet azokkal az állításokkal, melyek az iskolai dokumentumok megismerésének, elemzésének lehetőségére vonatkoztak. A visszajelzések alapján tehát a hallgatók vagy nincsenek ezzel tisztában, vagy segítséget, konkrétabb útmutatást igényelnének a feladat elvégzéséhez.

\begin{tabular}{|l|l|l|l|l|l|}
\hline & N & Min. & Max. & Átlag & Szórás \\
\hline Lehetőségem volt interjúk készítésére. & 22 & 1 & 5 & 3,45 & 1,654 \\
\hline $\begin{array}{l}\text { Lehetőségem volt a szaktárgyhoz } \\
\text { kapcsolódó helyi tanterv, tanmenet } \\
\text { megismerésére. }\end{array}$ & 21 & 1 & 5 & 3,52 & 1,327 \\
\hline $\begin{array}{l}\text { Megismertem az intézmény rendszerét, } \\
\text { fóbb dokumentumait. }\end{array}$ & 22 & 1 & 5 & 3,55 & 1,184 \\
\hline $\begin{array}{l}\text { Lehetőségem volt az iskolai } \\
\text { dokumentumok elemzésére. }\end{array}$ & 22 & 1 & 5 & 3,64 & 1,399 \\
\hline $\begin{array}{l}\text { Lehetőségem volt kérdő́ives vizsgálat } \\
\text { készítésére. }\end{array}$ & 22 & 1 & 5 & 3,64 & 1,590 \\
\hline
\end{tabular}

11.7. táblázat: A hallgatók egyetértésének mértéke az intézmény megismerését célzó kutatási lehetőségekre vonatkozóan a csoportos iskolai gyakorlatok során

$$
(\mathrm{N}=22)
$$

A vizsgálat kiterjed arra is, hogy a hallgatók mely gyakorlóiskolában végzett tevékenységet érezték a leghatékonyabbnak. A hallgatói visszajelzések alapján saját professzionális fejlődésükhöz legkiemelkedőbb mértékben az óratartás járult hozzá (8. táblázat). Ez megerősíti a korábbi hazai kutatási eredményeket, melyek szerint az egész tanárképzés leghatékonyabb részeként az óratartást élik meg a hallgatók (N. Kollár, 2011). Ezt követik 
a rangsorban a hospitálásokkal kapcsolatos teendők és a mikrotanítás jelentősége. A legkevésbé átlagosan a kutatási tevékenységeket (kérdőívkészítés, interjú, dokumentumelemzés) érezték hasznosnak a hallgatók, jóllehet ez utóbbi csoportban a válaszok között óriási szórás mutatkozik. A szórások hátterére az összefüggésvizsgálatok világítanak rá, amelyek azt mutatják, hogy akiknek lehetőségük volt a tevékenységeket elvégezni, azok sokkal pozitívabban nyilatkoztak annak építő jellegéről.

\begin{tabular}{|c|c|c|c|c|c|}
\hline & $\begin{array}{l}\text { N (részt } \\
\text { vett) }\end{array}$ & Min. & Max. & Átlag & Szórás \\
\hline Iskolai dokumentumok elemzése & 17 & 1 & 5 & 2,94 & 1,249 \\
\hline $\begin{array}{l}\text { Kérdőíves vizsgálat elvégzése } \\
\text { az iskolában }\end{array}$ & 14 & 1 & 5 & 3,07 & 1,269 \\
\hline $\begin{array}{l}\text { Interjúk készítése az iskolában } \\
\text { dolgozó kollégákkal }\end{array}$ & 13 & 1 & 5 & 3,15 & 1,463 \\
\hline Portfóliókészítés & 16 & 1 & 5 & 3,50 & 1,265 \\
\hline Hospitálási jegyzőkönyv készítése & 22 & 1 & 5 & 3,73 & 1,162 \\
\hline $\begin{array}{l}\text { Hospitálás tanórán kívüli } \\
\text { foglalkozáson }\end{array}$ & 15 & 1 & 5 & 4,13 & 1,060 \\
\hline Mikrotanítás & 16 & 2 & 5 & 4,25 & 1,000 \\
\hline $\begin{array}{l}\text { Tanórán kívüli foglalkozások } \\
\text { megtartása }\end{array}$ & 10 & 1 & 5 & 4,30 & 1,337 \\
\hline $\begin{array}{l}\text { Hospitálásokat követő } \\
\text { megbeszélések }\end{array}$ & 22 & 2 & 5 & 4,45 & ,858 \\
\hline $\begin{array}{l}\text { Hospitálás hallgatótársaim által } \\
\text { tartott órákon }\end{array}$ & 22 & 3 & 5 & 4,50 & ,673 \\
\hline Óravázlatok készítése & 22 & 1 & 5 & 4,50 & 964 \\
\hline Hospitálás vezetőtanárom óráin & 22 & 3 & 5 & 4,55 & ,739 \\
\hline $\begin{array}{l}\text { Megtartott tanórák átbeszélése } \\
\text { a vezetőtanárral }\end{array}$ & 22 & 2 & 5 & 4,59 & ,796 \\
\hline Tanórák megtartása & 22 & 3 & 5 & 4,73 &, 550 \\
\hline
\end{tabular}

11.8. táblázat: A csoportos gyakorlatok során megvalósult iskolai tevékenységek szerepe a professzionális szakmai fejlődésben a hallgatók véleménye szerint

$$
(\mathrm{N}=10-22)
$$




\section{Óratervezéssel és szervezéssel összefüggő területek}

A korábban említett óratartás hasznosságát erősíti az a tény is, hogy a hallgatók a saját tanári kompetenciák fejlődését az óratervezéshez (M: 4.7, SD: .72), valamint a szaktárgy oktatásához szükséges készségek fejlődésén (M: 4.3, SD: 1.01) érezték leginkább. Valamivel alacsonyabb mértékben, de átlagosan még mindig egyetértés mutatkozik a hallgatók között a tekintetben, hogy a csoportos gyakorlatok során fejlődtek a különböző munkaformák és módszerek alkalmazása (M: 4.1, SD: .96), a pedagógiai értékelés (M: 4.1, SD: 1.15) és a taneszközök alkalmazása terén is (M: 4.0 SD: .97) (9. táblázat). A jelöltek 64\%-a vélte úgy, hogy a vezetőtanár az esetek többségében segített neki a megfelelő módszerek, eszközök, munkaformák kiválasztásában (10. táblázat).

\section{Szülőkkel való együttmülködés és osztályfőnöki feladatok ellátása}

A hallgatók és az iskolában tanító tanárok egyaránt úgy vélik, hogy sem az egyetem, sem a gyakorlóiskola nem biztosítja a hallgatói kompetenciák fejlődését a szülőkkel való együttmủködés (M: 1.32; SD: .56) és az osztályfőnöki feladatok ellátása terén (M: 1.9, SD: 1.1) (9. táblázat). A hallgatók 73\%-a úgy érzi, egyáltalán nem, 23\%-a inkább nem fejlődött a szülőkkel való együttműködés terén. A hallgatók véleménye két kivételtől eltekintve egyöntetűnek mutatkozik abban a tekintetben, hogy nem volt lehetőség a szülőkkel való kapcsolatteremtésre (pl. szülői értekezleten való részvétel) a gyakorlat során.

Szintén egyöntetűen negatív visszajelzések érkeztek az osztályfönöki feladatokkal kapcsolatos fejlődés terén. Habár a hallgatók több mint fele (59\%) részt vett osztályfőnöki órán, csak 23\%-uknak volt lehetősége közreműködni a megvalósításban.

\section{Tehetséggondozás, felzárkóztatás, differenciálás}

A másik problémás terület az átlagostól eltérő képességek fejlesztése terén, a tehetséggondozás (M: 2.6, SD: 1.09) és a felzárkóztatás terén (M: 2.6, SD: 1.09) mutatkozott. Tehetséggondozó foglalkozáson a hallgatók csupán 18\%-a vett részt, és 9\%-a közreműködött a foglalkozások tartásában is. Felzárkóztató foglalkozásokon a hallgatók 5\%-a vett részt, de az ilyen tevékenység megvalósításban 13\%-uk közremủködött. Fejlesztő foglalkozásokon a hallgatók 27\%-a vett részt, és 5\%-a tartott is ilyen jellegü foglalkozást (vö.: 3. táblázat). (Noha az Útmutató szerint a szaktárgyi gyakorlat egyik eleme a fejlesztő, illetve tehetséggondozó foglalkozás látogatása kellene hogy legyen.) A vezetőtanárok által nyújtott támogatással többé-kevésbé elégedettnek bizonyultak a hallgatók. A jelöltek közel fele úgy vélte, a vezetőtanár az esetek többségében segített neki a különleges bánásmódot igénylő tanulók fejlesztésében, 37\%-uk szerint a tehetséggondozás megvalósitásában is (10. táblázat).

Összességében a hallgatók csupán 10\%-a, a gyakorlóiskolai tanároknak pedig már csak 3-4\%-a érezte úgy, hogy a gyakorlóiskola ezeken a területeken biztosítja a hallgatók szakmai 
fejlődését. Ehhez kapcsolódó szintén problémás terület, de már pozitívabb képet mutat, a tanórai differenciálás. A hallgatók válaszai között nagy eltérés mutatkozott a tekintetben, hogy a differenciálás terén mennyire érezték a fejlődésüket, de átlagosan közepes mértékben fejlődtek (M: 3.2, SD: 1.19). Differenciált tanórai foglalkozáson és azok megvalósításában a hallgatók 13,6\%-a vett részt. Ezzel összefüggésben a hallgatók csupán 16\%-a, a tanárok 8\%-a gondolja úgy, hogy a gyakorlóiskola felkészíti erre a feladatra a hallgatókat. Ez az arány meglehetősen alacsony, hiszen a gyermekek megismerése és az egyéni bánásmód terén szerzett tapasztalatok kiemelkedő célként fogalmazódnak meg az Útmutatókban (a tanárok számára pedig a NAT-ban).

\section{Fegyelmezés és konfliktuskezelés}

A hallgatók megítélése alapján a diákok közötti konfliktusok sajátosságainak megismerése (M: 2.8, SD: 1.2), valamint az iskolai konfliktusok kezeléshez kapcsolódó szakmai fejlődés átlagosan közepes mértékben (M: 3.27, SD: 1.16) valósult meg (9. táblázat). A tanórai problémamegoldás terén átlagos értelemben már pozitívabb válaszok születtek (M: 3.77, SD: 1.27). A hallgatóknak ugyanakkor jelentős része (64\%-a) úgy vélte, fegyelmezési problémák terén a legtöbb esetben számíthatott vezetőtanárára (10. táblázat). Érdemes megjegyezni, hogy míg a hallgatók 47\%-a érzi úgy, hogy a gyakorlóiskola a tanórai fegyelmezés területén biztosítja a fejlődést, a tanárok csupán 6\%-a gondolja ugyanezt (2. ábra).

\begin{tabular}{|l|l|l|l|l|l|}
\hline & N & Min. & Max. & Átlag & Szórás \\
\hline $\begin{array}{l}\text { Fejlödtem a szülőkkel való } \\
\text { együttmúködés terén. }\end{array}$ & 22 & 1 & 3 & 1,32 &, 568 \\
\hline $\begin{array}{l}\text { Fejlődtem az osztályfónöki feladatok } \\
\text { ellátása terén. }\end{array}$ & 22 & 1 & 5 & 1,91 & 1,151 \\
\hline $\begin{array}{l}\text { Fejlődtem a tehetséggondozás } \\
\text { területén. }\end{array}$ & 22 & 1 & 5 & 2,64 & 1,255 \\
\hline $\begin{array}{l}\text { Fejlódtem a tanulói felzárkóztatás } \\
\text { területén. }\end{array}$ & 22 & 1 & 5 & 2,64 & 1,093 \\
\hline $\begin{array}{l}\text { Fejlódtem a tanári munkához } \\
\text { kapcsolódó adminisztrációs feladatok } \\
\text { ellátása terén. }\end{array}$ & 22 & 1 & 5 & 2,68 & 1,427 \\
\hline $\begin{array}{l}\text { Megismertem a diákok közötti } \\
\text { konfliktusok sajátosságait, okait. }\end{array}$ & 22 & 1 & 5 & 2,82 & 1,296 \\
\hline $\begin{array}{l}\text { Fejlődtem a gyakorlóiskolában dolgozón } \\
\text { kollégákkal való együttmúköós terén. }\end{array}$ & 22 & 1 & 5 & 2,86 & 1,521 \\
\hline
\end{tabular}




\begin{tabular}{|l|l|l|l|l|l|}
\hline & N & Min. & Max. & Átlag & Szórás \\
\hline $\begin{array}{l}\text { Fejlödtem a kooperatív módszerek } \\
\text { alkalmazása terén. }\end{array}$ & 22 & 1 & 5 & 3,14 & 1,283 \\
\hline $\begin{array}{l}\text { Fejlődtem a tanórai differenciálás } \\
\text { terén. }\end{array}$ & 22 & 1 & 5 & 3,23 & 1,193 \\
\hline $\begin{array}{l}\text { Fejlődtem az iskolai konfliktuskezelés } \\
\text { terén. }\end{array}$ & 22 & 1 & 5 & 3,27 & 1,162 \\
\hline $\begin{array}{l}\text { Fejlődtem az osztálytermi } \\
\text { problémahelyzetek megoldása terén. }\end{array}$ & 22 & 1 & 5 & 3,77 & 1,270 \\
\hline $\begin{array}{l}\text { Fejlödtem a különböző taneszközök } \\
\text { alkalmazása terén. }\end{array}$ & 22 & 2 & 5 & 4,00 & 0,976 \\
\hline $\begin{array}{l}\text { Fejlődtem a különböző módszerek } \\
\text { alkalmazása terén. }\end{array}$ & 22 & 2 & 5 & 4,09 & 1,065 \\
\hline Fejlődtem a pedagógiai értékelés terén. & 22 & 1 & 5 & 4,09 & 1,151 \\
\hline $\begin{array}{l}\text { Fejlődtem a különböző munkaformák } \\
\text { (páros, egyéni, csoportos, frontális) } \\
\text { alkalmazása terén. }\end{array}$ & 22 & 2 & 5 & 4,09 & 0,921 \\
\hline $\begin{array}{l}\text { Fejlődtek a szaktárgy oktatásához } \\
\text { kapcsolódó készségeim. }\end{array}$ & 22 & 2 & 5 & 4,32 & 1,041 \\
\hline Fejlődtem az óratervezés terén. & 22 & 2 & 5 & 4,73 & 0,703 \\
\hline
\end{tabular}

11.9. táblázat: A hallgatók saját szakmai fejlődésükre vonatkozó elégedettsége az egyes területekhez kapcsolódóan $(\mathrm{N}=22)$

\begin{tabular}{|c|c|c|c|c|c|}
\hline & 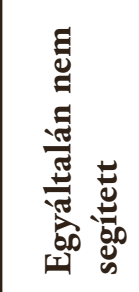 & 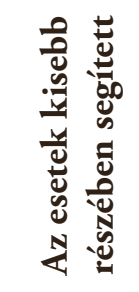 & 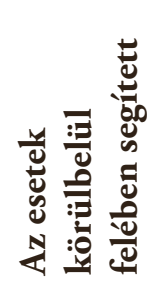 & 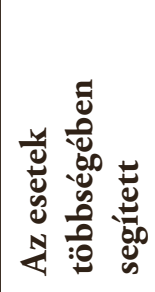 & 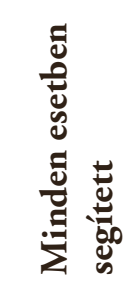 \\
\hline $\begin{array}{l}\text { Segített a megfelelő } \\
\text { módszerek, eszközök, } \\
\text { munkaformák } \\
\text { kiválasztásában. }\end{array}$ & $5 \%$ & $5 \%$ & $26 \%$ & $32 \%$ & $32 \%$ \\
\hline $\begin{array}{l}\text { Segített a tanulókkal való } \\
\text { hatékony kommunikáció } \\
\text { fejlesztésében. }\end{array}$ & $16 \%$ & $0 \%$ & $16 \%$ & $32 \%$ & $37 \%$ \\
\hline
\end{tabular}




\begin{tabular}{|c|c|c|c|c|c|}
\hline & 量 & 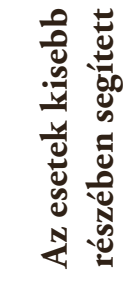 & 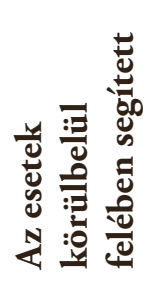 & 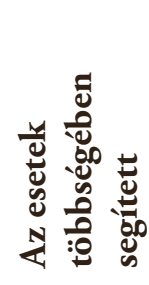 & 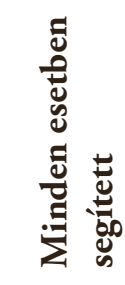 \\
\hline $\begin{array}{l}\text { Segített a különleges } \\
\text { bánásmódot igénylő tanulók } \\
\text { fejlesztésében. }\end{array}$ & $53 \%$ & $0 \%$ & $11 \%$ & $0 \%$ & $37 \%$ \\
\hline $\begin{array}{l}\text { Segített a tehetséggondozás } \\
\text { megvalósításában. }\end{array}$ & $42 \%$ & $0 \%$ & $11 \%$ & $16 \%$ & $32 \%$ \\
\hline $\begin{array}{l}\text { Segített a fegyelmezési } \\
\text { problémák megoldásában. }\end{array}$ & $5 \%$ & $5 \%$ & $26 \%$ & $32 \%$ & $32 \%$ \\
\hline
\end{tabular}

\subsection{0. táblázat: A szakvezető szakmai támogatásának hallgatói megítélése} az egyes területekhez kapcsolódóan $(\mathrm{N}=22$, relatív gyakoriság)

Amennyiben a hallgatók tantárgy-pedagógiai, szaktárgyi (tudományos) és pedagógiai-pszichológiai felkészültségével való hallgatói, vezetőtanári és oktatói elégedettséget nézzük, a következőket mondhatjuk. A vezetőtanárok és a hallgatók véleménye egyezést mutat a tekintetben, hogy a diszciplínák közül a jelöltek melyik téren a leginkább és melyik téren a legkevésbé felkészültek (11. táblázat). Ugyanakkor az is látható, hogy a vezetőtanárok sokkal kritikusabbnak tűnek a hallgatók felkészültségét illetően az egyes diszciplínák mentén. Az egyetemi oktatók viszont épp ellenkezőleg ítélték meg azokat. Úgy gondolják, hogy a jelöltek tantárgy-pedagógiai tudása a legerősebb, a szaktárgyi és a pedagógiai és pszichológiai tudásuk még igencsak fejlesztendő. Habár a vezetőtanárok a jelöltek pedagógiai-pszichológiai felkészültségével a legelégedettebbek, a nyílt kérdésekre adott válaszokból kiderül, hogy mit hiányolnak ezen a területen: „A tanitási órákon adódó nevelési helyzetekkel gyakran nem tudnak mit kezdeni, nem tudnak fegyelmezni, sokszor nehezen fejezik ki magukat, nem tudnak kérdéseket fogalmazni, és megfelelö hangerövel beszélni." "Igyekvők, de gyakorlati kérdésekben tapasztalatlanok, bizonytalanok.” "A megszerzett elméleti tudást a vizsga után hamar elfelejtik." „Kevés a gyerekek körében szerzett gyakorlati tapasztalatuk.” „Szegényes a pedagógiai eszköztáruk.”

A jelöltek szaktárgyi tudása tekintetében a vezetőtanárok szerint a hallgatók nem az iskolai gyakorlathoz kapcsolódó elméleti képzést kapják az egyetemen, ezért sok a szaktárgyi tévedésük a tanórákon („Az egyetemi képzésben megszerzett elméleti tudást nem mindig tudják alkalmazni a tanitás gyakorlatában és közel hozni a gyerekekhez úgy, hogy az érdekes és érthetö legyen”. "Sokszor elöször meg kell tanitani a hallgatónak az általa tanitandó anyagot, és csak utána lehet beengedni az osztályokba”.) 
A jelöltek szakmai felkészültségének megítélése a tantárgy-pedagógia terén a legalacsonyabb. A vezetőtanárok szerint ennek egyik oka, hogy a jelölteknek egyetemi tantárgy-pedagógiai tanulmányaik előtt már tanítaniuk kell. („A szinkronitás hiánya miatt nincsenek birtokában a még elözetesen elsajátitható tudásnak sem”. „A tanitási gyakorlat megkezdése elött a hallgatók legfeljebb egy önálló tervezetet készitenek, a vizsgára megtanult elméleti anyag is már többnyire feledésbe merült.")

\begin{tabular}{|c|c|c|c|c|c|c|}
\hline & \multicolumn{2}{|c|}{$\begin{array}{l}\text { Vezetőtanárok } \\
(\mathrm{N}=29)\end{array}$} & \multicolumn{2}{|c|}{$\begin{array}{l}\text { Hallgatók } \\
\text { (saját) }(\mathrm{N}=22)\end{array}$} & \multicolumn{2}{|c|}{$\begin{array}{l}\text { Egyetemi } \\
\text { szakmódszertanos } \\
\text { oktatók }(\mathrm{N}=20)\end{array}$} \\
\hline & Átlag & Szórás & Átlag & Szórás & Átlag & Szórás \\
\hline $\begin{array}{l}\text { A hallgatók tantárgy- } \\
\text { pedagógiai felkészültsége }\end{array}$ & 3,36 & 1,026 & 3,95 & 0,848 & 3.56 & 0.727 \\
\hline $\begin{array}{l}\text { A hallgatók szaktárgyi } \\
\text { (tudományos) } \\
\text { felkészültsége }\end{array}$ & 3,6 & 0,724 & 4,05 & 0,911 & 3.00 & 0.894 \\
\hline $\begin{array}{l}\text { A hallgatók pedagógiai- } \\
\text { pszichológiai } \\
\text { felkészültsége }\end{array}$ & 3,72 & 0,591 & 4,11 & 0,963 & 3.19 & 0.911 \\
\hline
\end{tabular}

11.11. táblázat: A tanárjelöltek felkészültéségére vonatkozó hallgatói, oktatói és tanári elégedettség

Az iskolai gyakorlat fejlesztésére vonatkozó hallgatói javaslatok egy jelentős része a szaktárgyi hospitálások számának emelésére vonatkozott. A hallgatók több (akár különböző tanárok által tartott) saját szakhoz kapcsolódó órát szeretnének megtekinteni. Az igények másik jelentős része a kihívást jelentő osztálytermi helyzetek kezelésére való hatékonyabb felkészítésre vonatkozott: „Esetmegbeszélések a tanitási gyakorlat elött”, "Jó lenne helyzetgyakorlatokat csinálni és megnézni, mi a helyes reakció egy-egy konfliktusra”, „Több szélsöséges esettel kellene találkoznunk, a gyakorlatban is átélni a differenciálás módszereit, az egyéni bánásmódot igénylö tanulókkal való foglalkozást”, „adott esetek megbeszélése, különbözö megoldási lehetöségek mérlegelésével". A jelöltek szerint sokat segítene az iskolai gyakorlatokra való felkészülésben, ha nem kellene párhuzamosan az egyetemi kurzusokat is látogatni, azokon teljesíteni, illetve azt az időt a gyakorlatok javára lehetne fordítani: „Véleményem szerint hatékonyabb lenne, ha a gyakorlat ideje alatt nem kellene az egyetemre órákra menni, csak a gyakorlatra koncentrálnánk”, „az egyetemi elöadások csökkentése az órákra való felkészülés és több gyakorlótanitás javára”, „rugalmasság a többi egyetemi órát tartó tanártól”. Felmerült annak igénye 
továbbá, hogy minél többféle órát, tanulócsoportot ismerhessenek meg a hallgatók („Több óra tartása és különböző osztályokban - különböző korosztályokban”, „Minél több tanulói csoportot ismerhessünk meg”), ugyanakkor arra is jelentős igény mutatkozott, hogy egy osztályt, csoportot jobban megismerhessen a jelölt („Egy adott osztállyal többet foglalkozni”).

A vezetőtanárok szerint az iskolai gyakorlat egyértelműen hatékonyabb lenne, ha a jelöltek több időt tölthetnének a gyakorlóiskolában, több hospitálással és óratartással („Több idöt kellene a gyakorlóiskolában tölteni. Az elsö idöszakban csak mint "szemlélödö«”, "A hallhatók hosszabb tanitási gyakorlatot végeznének”, „Tapasztaljanak, gyüjtsenek minél több gyakorlati órát a gyerekek között”, „Több tanitási lehetöséget adnék a hallgatóknak”, „Több gyakorlatra van a hallgatóknak szüksége. Ez nem elegendö.”). Többen úgy érzik, hogy a jelöltek elméleti felkészítése hiányos, ezért ehhez kapcsolódóan fogalmaztak meg javaslatokat: „Az egyetemi képzés során az elméleti képzést, majd a tantárgy-pedagógiai képzést olyan szakemberekre biznám, akik maguk is jártasak az adott területi (gyakorlóiskolai terület) képzésben. A tanitási gyakorlatot pedig csak a tantárgy-pedagógiai ismeretek elsajátitása után alkalmaznám.” „A módszertani ismeretek megszerzésének keretében gyakorolják a tervezet, illetve vázlat készitését konkrét iskolai tananyagra vonatkoztatva, hogy amikor a gyakorlóiskolába kerülnek, ne okozzon ekkora nehézséget az elkészitése." Néhányan a szakvezetők bevonását javasolták a szakmódszertan oktatásába.

\subsection{A tudásmegosztás lehetőségei}

A vizsgálat alapján elmondható, hogy többirányú tudásmegosztásról beszélhetünk a tanárjelöltek gyakorlóiskolai felkészítéséhez kapcsolódóan. Az „Azért jó, hogy az iskola gyakorlóiskolaként müködik, mert..." kezdetü nyílt kérdésre adott tanári válaszokból $(\mathrm{N}=120)$ kiderült, hogy a legmagasabb arányban a tanárok a színvonalas tudásközvetítésre való törekvésüket és az ehhez szükséges folyamatos szakmai megújulásukat jelölték meg (12. táblázat). A tudásmegosztáshoz kapcsolódóan a pedagógusok kiemelten fontosnak tartják az egyetemi kollégákkal való szakmai együttműködés lehetőségeit is. A gyakorlóiskolai tudásmegosztás nem egyirányú, hiszen többen kiemelték, hogy rengeteget tanulnak ők maguk is a hallgatóktól a folyamat során. A tanárjelöltek és egyetemi oktatók szakmai visszajelzései kiemelten fontosak a gyakorlóiskolai tanárok számára (vö. 5. táblázat). 


\begin{tabular}{|c|c|}
\hline Kategória & Példák tanári válaszokra \\
\hline $\begin{array}{l}\text { Színvonalas tudásközvetítés } \\
\text { és az ehhez szükséges folya- } \\
\text { matos szakmai megújulás } \\
\text { lehetősége }\end{array}$ & $\begin{array}{l}\text { „A »kirakatban« mindenki nagyobb tartással dolgozik, } \\
\text { és tudásának legjavát igyekszik átadni a diákoknak } \\
\text { és a hallgatóknak, valamint szakmailag folyamatosan } \\
\text { képezheti magát.” } \\
\text { „A diákok változatosabb órákon tanulhatnak, mint más } \\
\text { iskolákban.” } \\
\text { „A hallgatók miatt mindig meg kell újulni szakmailag, } \\
\text { és kreativitásból példát mutatni nekik.” } \\
\text { „A magas színvonal engem is folyamatos szakmai } \\
\text { fejlődésre ösztönöz.” } \\
\text { „A magas színvonalú oktató-nevelö munka, az innova- } \\
\text { tív környezet ösztönző a tanárjelöltek számára.” } \\
\text { „Naprakésznek kell lennünk szakmailag.” }\end{array}$ \\
\hline $\begin{array}{l}\text { Szakmai együttműködés } \\
\text { lehetősége az egyetemi } \\
\text { kollégákkal }\end{array}$ & $\begin{array}{l}\text { „A föiskolával/egyetemmel való együttmüködés sok } \\
\text { lehetőséget tartogat a diákok és tanárok számára. Így } \\
\text { folyamatos kapcsolat van az ifjabb és idősebb generáció } \\
\text { között szakmai és hozzáállás terén.” } \\
\text { „Jó szakmai kapcsolatot tudunk tartani } \\
\text { a szaktanszékekkel.” } \\
\text { „Kapcsolatban vagyok a hallgatókkal, a tanszékkel és } \\
\text { a szakmódszertanossal, meg tudjuk beszélni a feladato- } \\
\text { kat, problémákat.” } \\
\text { „Szélesebb az együttműködők köre, nemcsak önmagá- } \\
\text { ért dolgozik az iskola, hanem a hallgatókon keresztül } \\
\text { sokkal messzebbre is el tudja juttatni a szakmaiságot.” }\end{array}$ \\
\hline $\begin{array}{l}\text { Hallgatóktól való tanulás } \\
\text { lehetősége }\end{array}$ & $\begin{array}{l}\text { „A hallgatók mindig új színt és ötleteket hoznak.” } \\
\text { „A hallgatóktól is sokat lehet tanulni.” } \\
\text { „A legújabb nevelési-oktatási módszereket ismerhetjük } \\
\text { meg, szinte első kézből.” } \\
\text { „Átadhatjuk tudásunkat, tapasztalatunkat, miközben } \\
\text { mi is tanulunk.” }\end{array}$ \\
\hline
\end{tabular}

11.12. táblázat: „Azért jó, hogy az iskola gyakorlóiskolaként müködik, mert...” nyílt kérdés tudásközvetítésre vonatkozó tanári válaszok

$(\mathrm{N}=102$, relatív gyakoriság) 
Az óralátogatásokkal kapcsolatos kérdések alapján elmondható, hogy a hallgatók a meglátogatott gyakorlóiskolai órák színvonalával teljesen elégedettnek bizonyultak. Továbbá szignifikáns pozitív összefüggés rajzolódott ki az meglátogatott órák színvonala és a szakvezető pedagógiai $(\mathrm{r}=578, \mathrm{p}=0,005)$, illetve tantárgy-pedagógiai $(\mathrm{r}=0,660, \mathrm{p}$ = 0,001) tudásának megítélése között. (13. táblázat).

\begin{tabular}{|l|l|l|l|l|l|}
\hline & N & Min. & Max. & Átlag & Szórás \\
\hline $\begin{array}{l}\text { Elégedett voltam a meglátogatott órák } \\
\text { szakmai színvonalával. }\end{array}$ & 22 & 3 & 5 & 4,50 & 0,673 \\
\hline $\begin{array}{l}\text { Elégedett voltam a szakvezetőm } \\
\text { szakmódszertani (tantárgy-pedagógiai) } \\
\text { felkészültségével. }\end{array}$ & 22 & 2 & 5 & 4,55 & 0,858 \\
\hline $\begin{array}{l}\text { Elégedett voltam a szakvezetőm } \\
\text { pedagógiai felkészültségével. }\end{array}$ & 22 & 2 & 5 & 4,59 & 0,796 \\
\hline $\begin{array}{l}\text { Elégedett voltam a szakvezetőm } \\
\text { szaktárgyához kapcsolódó elméleti } \\
\text { felkészültségével. }\end{array}$ & 22 & 2 & 5 & 4,77 & 0,685 \\
\hline
\end{tabular}

11.13. táblázat: A hallgatók elégedettsége a szakvezetők pedagógiai, szakmódszertani és szaktárgyi felkészültségével, a meglátogatott órák szakmai színvonalával kapcsolatban $(\mathrm{N}=22)$

\section{5. Összegzés és javaslatok megfogalmazása}

A részvizsgálat célja az volt, hogy a szakmai fejlesztő iskola öt fö jellemzője (rendszerszintű gondolkodás, kísérletezés, egymástól való tanulás, saját kutatási tapasztalatokra épülő tanulás, tudásmegosztás) mentén megvizsgálja a gyakorlóiskola szerepét a tanárjelöltek felkészítésében. A részvizsgálathoz a tanulók $(\mathrm{N}=255)$, a gyakorlóiskolában tanító pedagógusok $(\mathrm{N}=102)$, a csoportos gyakorlaton lévő tanárjelöltek $(\mathrm{N}=22)$ és az egyetemi szakmódszertanos oktatók releváns kérdésekre adott válaszait vettük figyelembe.

\section{A tanárjelöltek felkészitésének tartalmi összehangolása (rendszerszintü gondolkodás)}

Az iskolai dokumentumokból jól kirajzolódik, hogy a gyakorlóiskola kiépítette az általa kitűzött célok eléréséhez szükséges hallgatói és vezetőtanári tevékenységek komplex rendszerét (SZMSZ, 2016, Sándor, 2011; Dudás, 2011). A dokumentumokban jól követhető, hogy a gyakorlóiskola mit, milyen céllal, milyen humán erőforrások által és hogyan kíván megvalósítani az iskolai gyakorlatokat illetően. A célok, az elvárások 
és a megvalósításhoz szükséges feltételek összhangban állnak egymással és az Oktatási Minisztérium által meghatározott rendelettel.

A rendszerszintű gondolkodás hiányaként azonosítottuk, hogy a szakvezetők, az egyetemi oktatók és maguk a tanárjelöltek is eltérően ítélik meg az egyetem és a gyakorlóiskola tanárképzésben betöltött szerepét. Ennek okaként az egyetemi és a gyakorlóiskolai képzés összhangjának hiányát látjuk.

Az egyetemi kurzusok szerepét különbözően érzékeli a két csoport. Jelentős eltérés rajzolódott ki a különböző munkaformák alkalmazása, a reflektivitás fejlesztése, az óravezetés, a tehetséggondozás területek esetében, amelyeknél a hallgatók sokkal fontosabbnak tartották az egyetem szerepét, mint a pedagógusok. A pedagógiai, szaktárgyi, pszichológiai területek szerepét pedig a pedagógusok érzik hangsúlyosabbnak a hallgatóknál. A hallgatók és a pedagógusok ennél hasonlóbban ítélik meg a gyakorlóiskola szerepét. Szerintük a gyakorlóiskola jelentős szerepet tölt be az óratervezési, -vezetési és tantárgy-pedagógiai tudásuk, valamint munkaformák és módszerek alkalmazásához kapcsolódó készségeik fejlesztésében. Bizonyos területeknél ugyanakkor a jelöltek intenzívebbnek érzékelik a gyakorlóiskola szerepét, mint a pedagógusok (pl. a tanulók értékelése, a fegyelmezés). A tanárok a tantárgy-pedagógiai tudás és tanítási módszerek területeket érzik erősebbnek a hallgatóknál.

\section{A tanárjelöltek kísérletezési lehetőségei a gyakorlótanítások során}

A kutatás alapján elmondható, hogy a tanárjelölteknek több lehetőségük is adódik a tanórákhoz kapcsolódó pedagógiai jellegű ötleteik megvalósítására, és döntő többségük úgy érzékeli, a megvalósitás nem ütközik falakba. A tanórán kívüli foglalkozásokba ugyanakkor kevesen tudnak bepillantást nyerni, és még kevesebben próbálhatják ki szakmai képességeiket ezeken a területeken (felzárkóztatás, tehetséggondozás). A kísérletezéshez hozzátartozik az intézményi szakmai háló megismerése (fejlesztő- és gyógypedagógusok, szülők, gyermekvédelmi szakember), amire szintén korlátozottan van lehetőségük a jelölteknek. (A hiányosságok hátterében a pedagógusi túlterheltség, a szervezti háló komplexitása, illetve a tanárjelöltek gyakorlóiskolai tevékenységeinek összehangolásával kapcsolatos nehézségek állnak.)

\section{Az egymástól való tanulás lehetőségei a tanárjelöltek szemszögéből}

A tanárok 80\%-a fontosnak tartja a hallgatók visszajelzéseit, és úgy véli, a jelöltekkel való együttműködés megfelelő szintű. Ugyanakkor az adatok alapján az is kirajzolódott, hogy a hallgatók 70\%-a úgy érezte, nem láthatott bele a nevelőtestület működésébe, és csupán 4\%-a érzékelte úgy, hogy része lehetett a nevelötestületnek mint szakmai közösségnek. A tanulók válaszaiból pedig kiderült, hogy a tanárjelöltek nem folynak bele az osztályok életébe. A tanárjelöltek hiányként fogalmazták meg, hogy nincs elég lehetőségük a tanári 
szerepek, az iskolában fejlesztő feladatokat ellátó kollégák és a szülőkkel való kapcsolattartás széles körű tanulmányázására. Mindezek a szakmai együttműködés kiszélesítésének további lehetőségeire hívják fel a figyelmet. Arról, hogy a megkérdezett csoportok milyen javaslatokat fogalmaznának meg a csoportos gyakorlatok hatékonyságának növelése érdekében, a következőket mondhatjuk összefoglalásul. Minden csoport megemlítette a hospitálások, valamint a tanított órák számának a növelését, a jelöltek megemlítették, hogy szeretnének több nem a szakjuknak megfelelő órát hospitálni és megnézni különböző tanítási stílusokat. Igényként fogalmazták meg a rájuk bízott osztályok, csoportok jobb megismerését. Szívesen vennék például a fegyelmezési problémák megoldásnak és az egyéni bánásmód képességének fejlesztését esetleírások segítségével. A szakvezetők szerint az egyetemi kurzusoknak gyakorlatorientáltabbnak kellene lenniük, ehhez pedig a tanárképzés tantervét át kellene gondolni, és összhangba kellene hozni a gyakorlóiskolai oktatással. Az egyetemi oktatók a képzésben részt vevő pedagógusokkal való párbeszéd hiányát említették, valamint hogy a hallgatóknak többféle órát és különböző szakvezetők óráit lenne szükséges hospitálniuk.

Az együttmúködés intenzitására vonatkozóan is fogalmazódtak meg igények. Folyamatos szakmai együttműködésre lenne szükség egyrészt azért, hogy a hallgatók a megfelelő időben, a megfelelő felkészültséggel legyenek jelen az intézményekben, másrészt azért, mert a képzési folyamathoz kapcsolódó elméleti és gyakorlati tevékenységek számának és tartalmának optimalizálása is fejlesztendő területként bontakozott ki.

\section{A tanárjelöltek saját tapasztalataira épülő tanulásának támogatása}

A kutatási eredmények igazolták, hogy a gyakorlóiskola kiemelkedő mértékben biztosítja a szaktárgy oktatásához kapcsolódó készségek fejloldését, beleértve a szaktárgyhoz kapcsolódó tervezési és értékelési folyamatokat, valamint a szaktárgy tanításához kapcsolódó módszerek, eszközök megismerését és kipróbálását. A meglátogatott órák színvonalával és a vezetőtanárok szakmai felkészültségével a hallgatók nagymértékben elégedettek. A kutatás során azonban kiderült, hogy az intézmény által kitűzött, tanárképzésben részt vevő hallgatók professzionális felkészítésére fókuszáló célok nem minden tekintetben tudnak megvalósulni a gyakorlatban. Egyik ilyen kérdéses területként a tanári professzió megismeréséhez kapcsolódó hallgatói kutatási feladatok csoportja rajzolódott ki. Az adatokból úgy tűnik, hogy csak minden második hallgatónak volt ezek (interjú, kérdőív, dokumentumelemzés stb.) elvégzésére lehetősége, ám ennek oka nem egyértelmű. A probléma okának feltárása azért is szükségszerű, mert azon hallgatók, akik teljesítették ezen követelményeket, egyértelműen érzékelték a feladatok fejlesztő hatását.

A célok megvalósulásának másik hiányterülete olyan problémákra irányítja a figyelmet, melyeket a tanárképzéshez kapcsolódó, korábbi szakirodalmi adatok is jeleztek (N. Kollár, 2008; Jancsák, 2012). Az egyéni bánásmódot igénylő tanulókkal való tanórai (differenciálás) 
vagy tanórán kívüli (felzárkóztatás, tehetséggondozás) foglalkozásokhoz kapcsolódó kompetenciák fejlődését átlagosan közepes vagy annál gyengébb mértékben érezték a hallgatók az iskolai gyakorlat során. Ezt a tény erősíti, hogy ezen területek azok többek között, amelyekre a hallgatók és a tanárok egyöntetű véleménye alapján az egyetemi kurzusok és a csoportos iskolai gyakorlatok legkevésbé biztosítják a felkészülést. Ezek az adatok egybecsengenek többek között a kezdő tanárok szakmai fejlődési igényeivel is (Jensen és mtsai., 2012). Ezek tehát rendszerszintű tendenciák, ugyanakkor azt a gyakorlóiskolának fontos lenne átgondolnia, mit tehet annak érdekében, hogy intézményi szinten csökkentse a probléma mértékét. Valószínűleg az egyéni összefüggő, külső iskolai gyakorlat során egy picit több magabiztosságot szerezhetnek ezeken a területeken a hallgatók, de fontos lenne, hogy a képzés minden szintjén kapjanak mankókat, lássanak jó gyakorlatokat.

A fegyelmezéshez kapcsolódó stratégiák, módszerek átbeszélésére nagy igény mutatkozik a hallgatók felől, akár tanóra előtti vagy tanórát követő esetelemzések keretében. A jelöltek a szülőkkel való kommunikáció terén sem érezték szakmai fejlődésüket a gyakorlótanítás során. Pedig nagyon fontos lenne, hogy a családokkal való pozitív és erős kapcsolat kialakításának módjait és lehetőségeit minél előbb megtapasztalják a hallgatók is. Különösen fontos ennek az együttműködésnek a megteremtése és erősítése az egyéni bánásmódot igénylő tanulók esetében. Ugyanakkor a szakvezetők feladata sem egyszerủ, ha szeretnék a hallgatókat bevonni ennek a kapcsolatnak az alakulásába. Komoly nehézséget jelenthet a csoportos gyakorlat szervezési feltételeinek (hallgatók kevés ideig és kis csoportban vannak jelen az iskolában), illetve a szülőkkel való intim kapcsolat kialakításának (pl. fogadóórán) összeegyeztetése. Talán erre alkalmasabb lehetőség kínálkozik a hallgatók összefüggő egyéni gyakorlata során, amikor sokkal hosszabb ideig és személyre szabottabban történik a hallgatók kompetenciafejlesztése. Addig is fontos tapasztalat lehet a hallgatók számára néhány, a tanár által felvázolt esettanulmány, amikor egy-egy tanulóval kapcsolatos nehézség, probléma mentén képet kaphatnak a családi háttérről, a családdal kapcsolatos teendők lehetőségéről.

A hallgatók és a vezetőtanárok megítélése szerint az iskolai gyakorlatok hatékonyságát egyértelműen növelhetné, ha a jelölteknek több (különböző korosztályban és tanulócsoportban történő) óralátogatási/óratartási lehetőséget biztosíthatna az intézmény beleértve, hogy a hallgatóknak többféle órát és különböző szakvezetők óráit lenne szükséges hospitálniuk. A vezetőtanárok szerint a hatékonyság növeléséhez hozzájárulna továbbá, ha az egyetem és a gyakorlóiskola képzési tartalma és ütemezése összhangban lenne egymással, így nem fordulhatna olyan elő, hogy a jelöltek az egyetemi kurzusokon megszerzett elméletet nem tudják hasznosítani a gyakorlatban, illetve hogy előbb tartanak a hallgatók szaktárgyi órát, mintsem a szakmódszertani kurzust elvégezték volna. Megfontolásra javasolt tehát az egyetemi oktatók és a gyakorlóiskolai tanárok szorosabb együttműködése, valamint az egyetemi képzési tartalom és a gyakorlóiskolai tevékenységek összefésülése. 


\section{A tudásmegosztás lehetőségei}

A szakmai fejlesztő iskola modellje a képzésben részt vevő intézmények és érintett személyek egyenrangú viszonyán alapul, melyre a kutatás alapján a tanárképzés több szintjén is igény és szükség mutatkozik. A gyakorlóiskolai tudásmegosztással kapcsolatban elmondható, hogy az ismeretközvetítés alapvetően a tanár/oktató irányából a hallgató felé történik. A tanárok közül ugyanakkor többen jelezték, hogy a hallgatóktól is rengeteget tanulnak, új módszereket, játékokat ismernek meg általuk. A vizsgálat rávilágított arra is, hogy bár a felek az együttmüködés szintjével elégedettek, a gyakorlótanítással kapcsolatban lévő tanárok és oktatók közötti tudásmegosztás hiányos. A jól működő szakmai tanulóközösségekben a tagoknak lehetőségük van kölcsönösen tanulni egymástól. Különösen fontos lenne, hogy ennek a tanulóközösségnek a szülők is aktív tagjává válhassanak, mert ezzel a hallgatók felkészülését jelentősen segíthetnék. Ugyanígy megemlíthető az iskolatitkár, iskolapszichológus és fejlesztőpedagógus szerepe is. Több lehetőséget kellene biztosítani a hallgatók számára az egyéni bánásmódot igénylő tanulókkal való tanórai (differenciálás) vagy tanórán kívüli (felzárkóztatás, tehetséggondozás, pszichológiai) foglalkozások megfigyelésére, illetve a szakemberekkel való együttmüködésre. Az együttműködés továbbá ki kellene hogy terjedjen a gyermekek és a tanárjelölt hallgatók tanulási szükségleteire vonatkozó közös kutatásokra is.

Összefoglalásul elmondhatjuk, hogy a részvizsgálat során kirajzolódott hiányosságok csak úgy csökkenthetők, ha a tanárképzés egy sokkal gyakorlatiasabb irányba mozdul el. A nemzetközi példák alapján ez megnyilvánulhat egyfelől az iskolai gyakorlatok diverzitásában, a gyakorlati idő növekedésében, a képzőintézmények és oktatók közötti új partnerségi modellek kialakításában (Zeichner, 2010; Kopp és Kálmán, 2015; Murray, 2019). Az egyetemalapú tanárképzés egyik legnagyobb problémájának az egyetemi kurzusok és a gyakorlóiskolai gyakorlat közötti diszharmónia tủnik, aminek oka, hogy a különböző intézményi szinteken nem kellő mértékű a szakmai együttmủködés. Mindezen probléma megoldása újfajta megközelítést igényel. Néhány strukturális változtatás nem elegendő, a kiegészítő jellegű egyetemalapú képzés irányából el kell mozdulni egy együttműködő, a partnerek számára egyenlő partneri viszonyt megtestesítő modell irányába. A szakmai fejlesztő iskola (Professional Development School) koncepciója egyike azoknak a szervezeti modelleknek, amelyek megoldást kínálnak a felsorolt problémákra. Természetesen ez szemléletbeli, szerkezeti és tartalmi változtatásokat igényel a tanárképzés rendszerében. Az együttmüködésre alapozott munka nemcsak a tanulók tanulását támogatja, hanem ösztönzi a kísérletezést, az innovációt és a kutatásokat. A pedagógusok szakmai együttmúködése kulcsfontossággal bír, mert növeli a tanárok szakmai énhatékonyságát és a munkájukkal való elégedettséget (OECD, 2014). Hozzájárul a tudásmegosztás széles körben való megvalósulásához és a tanárjelöltek, a pedagógusok és oktatók összetettebb és hatékonyabb szakmai fejlődéséhez. 


\section{Felhasznált források}

Carlson, H. L. (1999). From Practice to Theory: a social constructivist approach to teacher education. Teachers and Teaching: theory and practice, 5 (2), 203-218. https://doi.org/10.1080/1354060990050205

Dafinoiu, I. és Lungu, O. (2003). Research Methods in the Social Sciences / Metode de cercetare în ştiinţele sociale. Frankfurt am Main: Peter Lang, Internationaler Verlag der Wissenschaften.

Darling-Hammond, L. (2006). Constructing 21st-Century Teacher Education, Journal of Teacher Education, 57 (10), 1-15. https://doi.org/10.1177/0022487105285962

European Commission, (2015). „The Teaching Profession in Europe: Practices, Perceptions, and Policies", Eurydice Report. Luxembourg: Publications Office of the European Union.

Feiman-Nemser, S. (2001). From preparation to practice: Designing a continuum to strengthen and sustain teaching. Teachers College Record, 103(6), 1013-1055. https://doi.org/10.1111/0161-4681.00141

Furlong, J., Campbell, A., Howson, J., Lewis, S. és McNamara, O. (2006). Partnership in English Initial Teacher Education: Changing Times, Changing Definitions. Evidence from the Teacher Training Agency's National Partnership Project. Scottish Educational Review, 37: 32-45.

Garvin, D. A. (1993). Building a Learning Organization. Harvard Business Review, JulyAugust, 1993 Issue. Retrieved from https://hbr.org/1993/07/building-alearningorganization

Hagger, H., és McIntyre, D. (2006). Learning Teaching from Teachers: Realizing the Potential of School-based Teacher Education. London: McGraw-Hill.

International. Holmes Group, (1986). Tomorrow's teachers: A report of the Holmes Group, East Lansing, MI: Holmes Group. Holmes Group, (1990). Tomorrow's teachers: Principals for the design of professional development school. East Lansing, MI: Holmes Group.

Jancsák Csaba (2011). A tanárképzésben részt vevő hallgatók formálódó világa. In.: Ercsei Kálmán és Jancsák Csaba szerk. Tanárképzös hallgatók a bolognai folyamatban (2010-2011). OFI

Jancsák Csaba (2012). A tanárképzés hallgatói megítélése, In: A szociológia szemüvegén keresztül - Tanulmányok Feleky Gábor 60. születésnapjára, Szeged, Belverde Meridionale.

Jensen, B., Sandoval-Hernandez, A., Knoll, S. és Gonzales, E. J. (2012). The Experience of New Teachers: Results from TALIS 2008, Paris: OECD Publishing. 
https://doi.org/10.1787/9789264120952-en

Kocsis Mihály (2003). A tanárképzés megítélése. Iskolakultúra-könyvek 18.

Korthagen, F. és Kessels, J. P. (1999). Linking Theory and Practice: Changing the Pedagogy of Teacher Education. Educational Researcher, 28(4), 4-17. https://doi.org/10.3102/0013189X028004004

Ligeti György - Márton Izabella (2002). Jelentés a "Szülök és az iskola" címü kutatás eredményeiröl. Kurt Lewin Alapítvány.

Lukács Péter (et al.) (2002). A pedagógusképzés megújitásához. I. Budapest. Oktatáskutató Intézet.

Murray, J., Swennen és J., Kosnik, C. (2019). International Research, Policy and Practice in Teacher Education. Springer International Publishing. https://doi.org/10.1007/978-3-030-01612-8

N. Kollár Katalin (2008). Pedagógusok pályaképe, a tanárképzéssel való elégedettségük nehézségeik. Pedagógusképzés 6 (35) 5-29.

https://doi.org/10.37205/TEL-hun.2008.4.01

N. Kollár Katalin (2011). Tanárjelöltek pályaképe, képzéssel való elégedettségük és nehézségeik. Pedagógusképzés 9 (38) 5-29.

https://doi.org/10.37205/TEL-hun.2011.1-2.01

OECD, (2014). TALIS 2013 Results. An International Perspective on Teaching and Learning. The OECD Teaching and Learning International Survey (TALIS) - 2013 Results. Paris: OECD. https://doi.org/10.1787/9789264214293-fr https://doi.org/10.1787/9789264196261-en

OECD. (2009). Creating Effective Teaching and Learning Environments: First Results from TALIS (2009).

Putnam, R. és Borko, H. (2000). What do new views of knowledge and thinking have to say about research on teacher learning? Educational Researcher, 29(1), 4-15. Senge, P. M. (1990). The Fifth Discipline. New York: Dubbleday. https://doi.org/10.3102/0013189X029001004

Sági Matild - Szemerszki Marianna (2016). A pályakezdő pedagógusok szakmai fejlődési igényei és azok megvalósulása. In.: Fehérvári Anikó Szerk. (2016): Pedagóguskutatások: Merre tart a pedagógusszakma? OFI.

Stéger, Cs. (2014). State of play in teacher education in Hungary AFTER the Bologna reforms. Budapest: Eötvös University Press.

Vick, M. (2006). "It's a difficult matter": Historical perspectives on the enduring problem of the practicum in teacher preparation. Asia-Pacific Journal of Teacher Education, 34(2), 181-198. https://doi.org/10.1080/13598660600720579 


\section{Internetes források:}

15/2006. (IV.3.) OM rendelet az alap- és mesterképzési szakok képzési és kimeneti követelményeiről (Utolsó letöltés: 2018. augusztus 22.) http://www.felvi.hu/pub_ bin/dload/jogszabalyok/15_2006_alap_mester_kkk_20080201.pdf

Dudás Anna szerk. (2011): Útmutató a tanári mesterképzés szakos hallgatók nevelésioktatási gyakorlatához (Utolsó letöltés: 2018. augusztus 22.) https://drive.google. com/file/d/0BzreRR__Yf1pNF9rS1djQmgtaFE/view

Eszterházy Károly Főiskola Gyakorló Általános, Közép-, Alapfokú Művészeti Iskola és Pedagógia Intézet (2016), Nevelési program (Utolsó letöltés: 2018. augusztus 22.) https://drive.google.com/file/d/0BzreRR__YflpX1ZRT3kwcUFuTDg/view

Eszterházy Károly Főiskola Gyakorló Általános, Közép-, Alapfokú Művészeti Iskola és Pedagógia Intézet (2016): Szervezeti és Működési Szabályzat (Utolsó letöltés: 2018. augusztus 22.) https://drive.google.com/file/d/0BzreRR__Yf1pT0RrcHY5Uj hFNXM/view

Eszterházy Károly Főiskola Gyakorló Általános, Közép-, Alapfokú Művészeti Iskola és Pedagógia Intézet: Munkaterv (2016/2017) (Utolsó letöltés: 2018. augusztus 22.) https://drive.google.com/file/d/0BzreRR__Yf1pc2MwcldlQ3B0WEU/view

Eszterházy Károly Főiskola Gyakorló Általános, Közép-, Alapfokú Művészeti Iskola és Pedagógia Intézet (2016): Házirend https://drive.google.com/file/d/0BzreRR__Yf1p NWQxOUpFelM5RGc/view

Sándor József (szerk.) (2011): Útmutató a tanári mesterképzés szakos hallgatók iskolai, szakmai, tanítási gyakorlatához https://drive.google.com/file/d/0BzreRR__YflpV3FG cld0UmJqeXM/view

Kutatásunk mérőeszközeinek és statisztikai adatainak elérhetősége: https://drive.google.com/drive/folders/1KF3NzKZttQpkLYIeULoAOqGumMsNEjIS? usp=sharing 